\title{
RESISTANCE AGAINST Aeromonas hydrophila INFECTION AND GROWTH OF SECOND GENERATION (F2) AFRICAN CATFISH [Clarias gariepinus] USING SELECTED MOLECULAR MARKERS
}

\author{
ALIMUDDIN $^{1 *}$, FADHILA MAHARANI PUTRI ${ }^{1}$, DINAMELLA WAHJUNINGRUM ${ }^{1}$, \\ DIAN HARDIANTHO ${ }^{2}$, ADE SUNARMA $^{2}$ and SRI NURYATI \\ ${ }^{1}$ Department of Aquaculture, Faculty of Fisheries and Marine Science, Institut Pertanian Bogor, \\ Bogor 16680, Indonesia \\ ${ }^{2}$ Main Center for Freshwater Aquaculture, Sukabumi 43114, Indonesia
}

Received 15 December 2016 / Accepted 01 August 2017

\begin{abstract}
Aeromonas hydrophila is a pathogenic bacteria that causes mass mortality in catfish. In previous studies, specific pathogen resistant (SPR), A. bydrophila-resistant African catfish first generation (F1) has been cultivated by marker assisted selection using the major histocompatibility complex (MHC) 1 as a molecular marker. In this study, growth performance, inheritance of the MHC DNA marker in the second generation (F2) of catfish and disease resistance against $A$. hydropbila infection were observed. The F2 progenies were produced by crossing F1 fish between themselves. Nursery was performed in 80-L glass aquaria, 4 replications for each cross, at the same initial density, for 2 months of rearing. The results showed that daily growth rate of F2 progenies from the SPR broods was significantly higher than those from broods without the marker. Results of the PCR analysis showed that average number of F2 progenies from SPR broods carrying the MHC marker was about 91\% higher than that of control. After the fish reached about $12 \mathrm{~cm}$ body length, they were challenged by intramuscularly injecting of $0.1 \mathrm{~mL} A$. bydrophila $\left(\mathrm{LD}_{50}: 10^{6}\right.$ $\mathrm{CFU} \mathrm{ml}^{-1}$ ) for 7 days. Results of challenge test showed that survival of F2 offspring from the crosses of SPR broods $(77.2 \%)$ was about two times higher than those from brood without MHC marker (38.3\%). Differential leukocyte count supported the high resistance of F2 progenies from F1 broods having MHC I marker against $A$. bydropbila infection. In conclusion, African catfish farming carrying MHC marker potentially have higher productivity and reduces fish lose due to infection by $A$. bydrophila.
\end{abstract}

Keywords: Aeromonas bydrophila, African catfish, disease resistance, growth, MHC I

\section{INTRODUCTION}

African catfish (Clarias gariepinus) is one of Indonesia's leading freshwater aquaculture species (MMAF 2016). Efforts to increase African catfish production is continuously done through aquaculture intensification. However, farmers often suffer loss from low survival rate, whether during nursery or growing phase. Low survival is usually caused by Aeromonas hydrophila bacterial infection which can result in $90 \%$ mortality in catfish (Zhang et al. 2016). Genetically specific pathogen resistant African catfish cultivation can be an alternative in preventing loss caused by the infection of this disease.

\footnotetext{
* Corresponding author: alimuddin@apps.ipb.ac.id
}

Cultivating disease resistant catfish can be done through conventional selection, however, this method takes relatively long time; for example, dropsy-resistant Kasnodar common carp (Cyprinus carpio) development took 9 generations (Kirpichnikov 1999). The alternative effort is molecular marker assisted selection. This method has been successfully utilized to develop Majalaya variety of common carp resistant against KHV infection (Alimuddin et al. 2011), and KHV resistant common carp variety has passed variety evaluation test and spread to farmers in 2015. In our previous research through challenge test, differences of endurance against $A$. bydropbila infection was found in African catfish (Azis et al. 2015a). PCR analysis with specific primer for 
major histocompatibility complex I (MHC I) gene showed that there are differences between fishes that lived or died post $A$. bydrophila bacterial infection (Azis et al. 2015a). MHC's role in the immune system is to represent antigen. With this result, we suggested that MHC I can be used as a molecular marker of $A$. bydrophila infection resistant African catfish. Afterward, challenge test with $A$. bydrophila against the first generation (F1) of crossing between fishes exhibiting molecular marker showed that the resistance can be inherited. The survival rate is about 2.2 times higher than F1 of fish with no molecular marker. MHC I molecular marker can be inherited by F1 generation with $62.5-83.4 \%$ percentage, while for control its only $25.0 \%$ (Azis et al. 2015b).

In this research, second generation (F2) of African catfish was produced by crossing F1 fishes exhibiting MHC I markers. The purpose of this research was to evaluate marker inheritance, resistance against $A$. bydrophila and growth during nursery.

\section{MATERIALS AND METHODS}

\section{Identification of F1 Broods Carrying MHC Marker}

Identification of fish having the MHC I marker was conducted by following Azis et al. (2015a) method. A total of five pairs matured broods were randomly taken from the pond. Their genomic DNA was extracted from fin tail tissue using DNA isolation kit (Puregene, Minneapolis, USA) by following manufacturer instruction. DNA was diluted with $50 \mathrm{~mL}$ sterile distilled water (SDW). Purity and DNA content was measured using spectrophotometer (Gene Quant) at 260 $\mathrm{nm}$ and $280 \mathrm{~nm}$ wavelength.

PCR amplification was performed at $25 \mathrm{~mL}$ final reaction volume. The solution of reaction consisted of $2.50 \mu \mathrm{L} 10 \mathrm{x}$ PCR buffer, $2 \mu \mathrm{L}$ dNTP mix, $2 \mu \mathrm{L}$ of forward and reverse CIMHAh-01 primers, $0.25 \mu \mathrm{LTaqDNA}$ polymerase (KAPA Biosystems), $1 \mu \mathrm{L}$ genomic DNA and $17.25 \mu \mathrm{L}$ SDW. Pre-denaturation of PCR process was performed at $94^{\circ} \mathrm{C}$ for $3 \mathrm{~min}, 35$ cycles of amplification with denaturation at $95^{\circ} \mathrm{C}$ for $30 \mathrm{sec}$, annealing at $68^{\circ} \mathrm{C}$ for $20 \mathrm{sec}$, and extension at $72^{\circ} \mathrm{C}$ for $30 \mathrm{sec}$, and a final extension at $72^{\circ} \mathrm{C}$ for 5 min. PCR products were separated by electrophoresis on $1.5 \%(\mathrm{w} / \mathrm{v})$ agarose gel, at 70 volts for $90 \mathrm{~min}$. DNA was visualized using red gel (Biotum Inc. California, US) and UV transilluminator.

\section{Production and Maintenance of F2 Generation}

Three pairs of F1 African catfish broodstock carrying MHC I marker and sexually mature were chosen. Ovulation and spermiation were induced by injecting ovaprim (Syndel Laboratories Ltd) with $0.2 \mathrm{mLkg}^{-1}$ dosage. Artificial fertilization was done by mixing eggs with sperm in a plastic container. F2 progeny was also developed by mating catfish broodstocks that did not exhibit MHC I marker as a control.

Eggs were incubated in 80 liter aquarium. African catfish were reared for 2.0 months, at the same initial density. Fishes were given tubificid as live food from 3 days until 30 days after hatching $(\mathrm{DAH})$, ad libitum. In 28-32 DAH, in addition to tubificid, fishes were also fed with PF-1000 commercial feed until $60 \mathrm{DAH}$. Afterward the fishes were fed Hi-Provit commercial feed until end of research. Commercial feed was given three times daily, at satiation. To keep good water quality, aquarium water replacement was conducted for $80 \%$ of total amount every two days. Water quality was measured before and after water replacement. Oxygen and ammonia concentration was measured by titration method (APHA 2005), whereas temperature and $\mathrm{pH}$ were directly measured by using thermometer and $\mathrm{pH}$ meter.

\section{Analysis of Marker Inheritance and Growth Performance}

F2 progenies having the MHC I marker identification was carried out by PCR method as described above. MHC I marker identification was conducted on 20 DAH F2 fishes. A total of 30 individual $\mathrm{F} 2$ progenies were randomly taken from each cross to determine MHC I marker inheritance.

Growth performance test on $\mathrm{F} 2$ progenies was conducted for two months. A total of 30 fishes (body weight $0.11 \pm 0.03 \mathrm{~g}$ ) were taken from each cross which carried and did not carried MHC I marker. Three replications were taken from each cross. Weighing were conducted every two weeks. 
The number of fish was counted at the end of the research to determine survival rate.

\section{Challenge Test against Aeromonas bydrophila}

Aeromonas bydrophila isolate was obtained from Fish Health Laboratory, Department of Aquaculture, IPB. A total of 20 fishes (total body length $11-12 \mathrm{~cm}$ ) of each cross were challenged by intramuscularly injecting $0.1 \mathrm{~mL}$ of $A$. bydrophila $\left(\mathrm{LD}_{50}: 10^{6} \mathrm{cfu} \mathrm{mL}^{-1}\right.$; this was obtained from our preliminary study). Negative control fishes were injected with $0.1 \mathrm{~mL}$ phosphate buffer saline. The fish were kept in 80-L volume glass aquaria and each cross had three aquariums as replications. Observations during challenge test treatment involved erythrocyte count, leucocyte count and differentiation, hematocrit, clinical signs, and mortality. Blood samples of nine fishes from each cross were taken before and after challenge. The number of erythrocytes and leukocytes were analyzed by using the method of Blaxhall and Daisley (1973), and hematocrit by Anderson and Siwicki (1995).

\section{Data Analysis}

Growth rate, survivability and blood count were analyzed with ANOVA with the help of Microsoft Excel 2011 and SPSS version 21.0 program with $95 \%$ confidence interval. Data that were significantly different was analyzed further by Duncan Multiple Range (DMR) test. MHC I marker inheritance data on F2 generation, and quality of water rearing were analyzed by descriptive statistics.

\section{RESULTS AND DISCUSSION}

\section{MHC I Marker Inheritance and Post Challenge Survivability}

Utilizing method introduced by Azis et al. (2015b), MHC I marker inheritance percentage from marker exhibiting broods obtained values ranging between $77.0-97.0 \%$, whereas broodstock without marker (control) had 46.6\% (Table 1). Challenge test result showed that survival of F2 African catfish from MHC I marker exhibiting broodstocks was higher $(\mathrm{p}<0.05)$ compared to control without the marker (cross D: $38.3 \pm 7.6 \%$ ).
Survival of A, B and C cross were $76.7 \pm 7.6 \%$, $80.0 \pm 5.0 \%$ and $75.0 \pm 5.0 \%$, respectively. Meanwhile, negative control fish from every cross injected with PBS all survived. This showed that fish mortality was a result of $A$. bydrophila bacterial infection.

Our previous research has produced F1 Afican catfish through MHC I molecular marker based selection (Azis et al. 2015b). In this research, F2 African catfish were challenged against Aeromonas bydrophila infection. F2 African catfish resistant was consistent with the F1 fish, in which the offsprings of broodstock exhibiting MHC I marker have higher resistance compared to fishes whose broodstocks did not (Table 1). The high survival of $\mathrm{F} 2$ fish post $A$. bydrophila challenge was consistent with the percentage of individuals carrying the marker, which was higher compared to fishes whose parent did not carry MHC I marker. The number of F2 fish from marker exhibiting parent cross was approximately 2 times higher compared to those whose parent did not exhibit MHC I marker (Table 1). The inheritance of marker in F2 fishes (77.0-97.0\%) was relatively similar to what was reported in F1 fish by Azis et al. (2015b), which is $62.6-83.4 \%$. This suggests that the MHC I marker was passed on to F2 offsprings. Similar pattern has also been found in the inheritance of Cyca-DAB $1 * 05$ MHC II marker in Indonesian common carp resistant to pathogen infection; $70.0 \%$ and $83.3 \%$ in the $\mathrm{F} 1$ and F2 generation, respectively (Decree of Marine and Fishery Minister No.24/KEPMEN$\mathrm{KP} / 2015)$.

MHC consists of many genes and is polymorphic (Rakus 2008). The oligonucleotide primer used in this study generates three DNA bands of PCR amplification product (Azis et al. 2015b). These three DNA PCR products are suspected to be different genes of the MHC I group (Azis et al.2015a). The selection performed on African catfish has not yet utilized one of those genes, thus the inheritance of the MHC I gene marker did not follow Mendelian segregation pattern. In addition, F2 fish from parents without MHC I marker were also found to be positive for the DNA marker.

The number of F2 fish suffering from ulceration was fewer than in fishes whose parent did not exhibit MHC I marker. The same occurrence was found in F1 fish (Azis et al. 2015b). DNA analysis by PCR revealed that 76\% 
Table 1 Percentage of MHC I marker inheritance and survival of African catfish second generation post Aeromonas bydrophila bacterial infection

\begin{tabular}{lcccc}
\hline \multirow{2}{*}{ Parameter } & \multicolumn{4}{c}{ Crosses } \\
\cline { 2 - 5 } & $\mathrm{A}$ & $\mathrm{B}$ & $\mathrm{C}$ & $\mathrm{D}$ \\
\hline Fish carrying the marker $(\%)$ & 93.0 & 77.0 & 97.0 & 46.7 \\
Survival rate $(\%)$ & $76.7 \pm 7.6^{\mathrm{b}}$ & $80.0 \pm 5.0^{\mathrm{b}}$ & $75.0 \pm 5.0^{\mathrm{b}}$ & $38.3 \pm 7.6^{\mathrm{a}}$ \\
\hline
\end{tabular}

Note: $\mathrm{A}=$ Cross of $\mathrm{R}_{1} \times \mathrm{R}_{1}$ A frican catfish broods exhibiting MHC I marker, $\mathrm{B}=$ Cross of $\mathrm{R}_{2} \mathrm{x} \mathrm{R}_{2}$ African catfish broods exhibiting $\mathrm{MHC}$ I marker, $\mathrm{C}=\mathrm{Cross}$ of $\mathrm{R}_{3} \times \mathrm{R}_{3}$ African catfish broods exhibiting MHC I marker, $\mathrm{D}=$ Cross of African catfish control group that did not exhibit MHC I marker. Different superscript letter in the same row showed a significant difference $(\mathrm{p}<0.05)$.

of dead fish from parents not exhibiting MHC I marker $(\mathrm{n}=25)$ did not carry MHC I marker (data not shown). This showed a strong correlation between the presence of MHC I marker with fish survival against $A$. bydrophila infection.

\section{Blood Count and Clinical Symptoms}

Blood count analysis result is presented in Table 2. Generally, erythrocyte count, leucocyte count and hematocrit from fishes of all cross before challenge were similar. Erythrocyte count of African catfish before challenge ranged between 2.13-2.83 $\left(\times 10^{6}\right.$ cell $\left.\mathrm{mm}^{-3}\right)$, leucocyte count was about 2.93-4.35 $\left(\times 10^{4}\right.$ cell $\left.\mathrm{mm}^{-3}\right)$ and hematocrit around $35.80-39.40 \%$. After the challenge, leucocyte count between challenged crosses was similar, and each lower $(p<0.05)$ compared to control that were not challenged by A. bydropbila or only injected by PBS (KA, KB, KC, and KD). Meanwhile, hematocrit level of all cross challenged by bacteria suffered decrease compared with PBS injected control (Table 2). Leucocyte counts of fishes injected by PBS (Ka,
$\mathrm{KB}, \mathrm{KC}$ and $\mathrm{KD}$ ) were lower compared to A, B, C and $\mathrm{D}$ cross that were challenged (Table 2 ).

Before the challenge test, blood count analysis showed that F2 African catfish were healthy. It was shown by the erythrocyte count, leucocyte count, and hematocrit which was within the range of healthy catfish (Table 2). The erythrocyte count range of healthy catfish is 2.0-3.0 $\left(\times 10^{6}\right.$ cellmm ${ }^{-3}$ ) (Hastuti \& Subandiyono 2015), total leucocyte count ranged 1.83-4.22 $\left(\mathrm{x} 10^{4} \mathrm{cell} / \mathrm{mm}^{3}\right)$ (Triyaningsih et al. 2014) and hematocrit value between 30.8-45.5\% (Yanto et al. 2015). Immune response of $\mathrm{F} 2$ fish against $A$. hydrophila bacterial infection can be inferred from complete blood count parameter. After challenge, erythrocyte count decreased to $1.50-1.82\left(\times 10^{6}\right.$ cellmm $\left.^{-3}\right)$, and hematocrit value to $20.2-25.0 \%$ (Table 2). Ulcer in infected fish caused blood vessel to burst and decrease erythrocyte count. Ulceration was the result of bacterial hemolysin toxin on fish's body surface (Del Coral et al. 1990). In contrast, as shown in Table 2, after the challenge, leucocyte count increased to $6.11-7.04\left(\times 10^{4}\right.$ cellmm $\left.{ }^{-3}\right)$. This increase is the fish's response to defending

Table 2 Erythrocyte count, leucocyte count, and hematocrit of second generation African catfish from parents exhibiting MHC I marker before and after Aeromonas hydrophila injection

\begin{tabular}{ccccccc}
\hline \multirow{2}{*}{$\begin{array}{c}\text { Treat } \\
\text { ment }\end{array}$} & \multicolumn{2}{c}{ Erythrocyte $\left(\mathrm{x} 10^{6}\right.$ cell $\left./ \mathrm{mm}^{3}\right)$} & \multicolumn{2}{c}{ Leucocyte $\left(\mathrm{x} 10^{4} \mathrm{sel} / \mathrm{mm}^{3}\right)$} & \multicolumn{2}{c}{ Hematocrit $(\%)$} \\
\cline { 2 - 6 } & Prechallenge & Postchallenge & Prechallenge & Postchallenge & Prechallenge & Postchallenge \\
\hline $\mathrm{A}$ & $2.38 \pm 0.09^{\mathrm{a}} \mathrm{b}$ & $1.58 \pm 0.11^{\mathrm{a}}$ & $4.35 \pm 0.09^{\mathrm{a}}$ & $6.97 \pm 0.37^{\mathrm{a}}$ & $35.80 \pm 1.02^{\mathrm{a}}$ & $23.20 \pm 3.22^{\mathrm{a}}$ \\
$\mathrm{B}$ & $2.42 \pm 0.43^{\mathrm{ab}}$ & $1.82 \pm 0.79^{\mathrm{a}}$ & $3.66 \pm 0.38^{\mathrm{a}}$ & $6.27 \pm 0.87^{\mathrm{a}}$ & $37.20 \pm 1.95^{\mathrm{ab}}$ & $25.00 \pm 0.69^{\mathrm{a}}$ \\
$\mathrm{C}$ & $2.13 \pm 0.25^{\mathrm{a}}$ & $1.50 \pm 0.33^{\mathrm{a}}$ & $3.87 \pm 0.25^{\mathrm{a}}$ & $6.11 \pm 0.84^{\mathrm{a}}$ & $36.60 \pm 0.65^{\mathrm{ab}}$ & $22.50 \pm 3.21^{\mathrm{a}}$ \\
$\mathrm{D}$ & $2.64 \pm 0.44^{\mathrm{ab}}$ & $1.74 \pm 0.11^{\mathrm{a}}$ & $3.95 \pm 0.96^{\mathrm{a}}$ & $7.04 \pm 0.72^{\mathrm{a}}$ & $37.60 \pm 2.17^{\mathrm{ab}}$ & $20.20 \pm 4.27^{\mathrm{a}}$ \\
\hline $\mathrm{KA}$ & $2.63 \pm 0.38^{\mathrm{a}}$ & $3.09 \pm 0.17^{\mathrm{b}}$ & $4.07 \pm 0.64^{\mathrm{a}}$ & $3.27 \pm 1.06^{\mathrm{b}}$ & $37.70 \pm 1.14^{\mathrm{ab}}$ & $33.30 \pm 3.89^{\mathrm{b}}$ \\
$\mathrm{KB}$ & $2.61 \pm 0.33^{\mathrm{a}}$ & $3.27 \pm 0.21^{\mathrm{b}}$ & $3.75 \pm 0.26^{\mathrm{a}}$ & $3.05 \pm 0.33^{\mathrm{b}}$ & $37.70 \pm 2.29^{\mathrm{ab}}$ & $38.80 \pm 1.89^{\mathrm{b}}$ \\
$\mathrm{KC}$ & $2.58 \pm 0.30^{\mathrm{ab}}$ & $3.32 \pm 0.11^{\mathrm{b}}$ & $3.32 \pm 0.11^{\mathrm{a}}$ & $3.26 \pm 0.44^{\mathrm{b}}$ & $38.90 \pm 0.93^{\mathrm{b}}$ & $40.60 \pm 2.82^{\mathrm{b}}$ \\
$\mathrm{KD}$ & $2.83 \pm 0.16^{\mathrm{b}}$ & $2.93 \pm 0.13^{\mathrm{b}}$ & $2.93 \pm 0.13^{\mathrm{a}}$ & $2.98 \pm 0.04^{\mathrm{b}}$ & $39.40 \pm 0.55^{\mathrm{b}}$ & $38.80 \pm 2.65^{\mathrm{b}}$ \\
\hline
\end{tabular}

Note: $A=$ Cross of $\mathrm{R}_{1} \times \mathrm{R}_{1}$ African catfish broods exhibiting MHC I marker, B = Cross of $\mathrm{R}_{2} \times \mathrm{R}_{2}$ African catfish broods exhibiting MHC I marker, $\mathrm{C}=\mathrm{Cross}$ of $\mathrm{R}_{3} \times \mathrm{R}_{3}$ African catfish broods exhibiting MHC I marker, $\mathrm{D}=$ Cross of African catfish control group that did not exhibit MHC I marker. Ka, KB, $\mathrm{KC}$, and $\mathrm{KD}$ respectively are fish from A, B, C, and D crossing injected by phosphate buffer saline (PBS). Different superscript letter in the same coloumn showed a significant difference $(p<0.05)$ 
Table 3 Lymphocyte, neutrophil, and monocyte percentage of second generation African catfish from parents exhibiting MHC I marker challenged by Aeromonas hydrophila bacteria

\begin{tabular}{cccc}
\hline \multirow{2}{*}{ Treatment } & \multicolumn{3}{c}{ Leucocyte differentiation (\%) } \\
\cline { 2 - 4 } & $72.00 \pm 2.08^{\mathrm{b}}$ & Neutrophyl & Monocyte \\
\hline A & $75.00 \pm 6.00^{\mathrm{bc}}$ & $18.00 \pm 4.51^{\mathrm{c}}$ & $10.00 \pm 3.46^{\mathrm{cd}}$ \\
$\mathrm{B}$ & $79.00 \pm 1.53^{\mathrm{c}}$ & $16.00 \pm 3.79^{\mathrm{bc}}$ & $9.00 \pm 2.89^{\mathrm{bc}}$ \\
C & $62.00 \pm 2.52^{\mathrm{a}}$ & $12.00 \pm 3.00^{\mathrm{b}}$ & $9.00 \pm 3.79^{\mathrm{bcd}}$ \\
D & $88.00 \pm 3.61^{\mathrm{d}}$ & $26.00 \pm 2.52^{\mathrm{d}}$ & $14.00 \pm 3.61^{\mathrm{d}}$ \\
\hline KA & $93.00 \pm 1.53^{\mathrm{d}}$ & $7.00 \pm 1.53^{\mathrm{a}}$ & $5.00 \pm 3.06^{\mathrm{a}}$ \\
KB & $91.00 \pm 2.08^{\mathrm{d}}$ & $4.00 \pm 0.58^{\mathrm{a}}$ & $4.00 \pm 1.15^{\mathrm{ab}}$ \\
KC & $91.00 \pm 0.58^{\mathrm{d}}$ & $5.00 \pm 0.33^{\mathrm{a}}$ & $2.00 \pm 1.00^{\mathrm{a}}$ \\
KD & $6.00 \pm 0.01^{\mathrm{a}}$ & $3.00 \pm 0.58^{\mathrm{a}}$ \\
\hline
\end{tabular}

Note: $A=$ Cross of $R_{1} \times R_{1}$ African catfish broods exhibiting MHC I marker, $B=$ Cross of $R_{2} \times R_{2}$ African catfish broods exhibiting MHC I marker, $C=C$ ross of $\mathrm{R}_{3} \mathrm{xR}_{3}$ African catfish broods exhibiting MHC I marker, $\mathrm{D}=$ Cross of African catfish control group that did not exhibit MHC I marker. Ka, KB, $\mathrm{KC}$, and $\mathrm{KD}$ respectively are fish from $\mathrm{A}, \mathrm{B}, \mathrm{C}$, and D crossing injected by phosphate buffer saline (PBS). Different superscript letter in the same column showed a significant difference $(\mathrm{p}<0.05)$.

against pathogen infection (Li et al. 2013; Hastuti \& Subandiyono 2015).

Leucocyte differentiation was only observed post-infection (Table 3). Lymphocyte count of fishes challenged by $A$. bydrophila bacteria was lower compared to those injected by PBS $(\mathrm{p}<0.05)$. Lymphocyte count of $\mathrm{D}$ cross fish $(62.00 \pm 2.52 \%)$ challenged by $A$. bydrophila was lower $(\mathrm{p}<0.05)$ compared to A cross $(72.00 \pm$ $2.08 \%), \mathrm{B}$ cross $(75.00 \pm 6.00 \%)$, and $\mathrm{C}$ cross $(79.00 \pm 1.53 \%)$. Neutrophyl count of fish injected with PBS (4.00-7.00\%) was lower compared to those challenged by $A$. hydrophila $(\mathrm{p}<0.05)$. Between challenged crosses, D cross fishes $(26.00 \pm 2.52 \%)$ had higher neutrophyl count compared to A cross $(18.00 \pm 4.51 \%), \mathrm{B}$ $(16.00 \pm 3.79 \%)$, and $C$ cross $(12.00 \pm 3.00 \%)$. Monocyte count was also higher in fishes challenged by $A$. bydrophila bacteria $(\mathrm{p}<0.05)$, and monocyte count between all crosses were similar $(\mathrm{p}>0.05)$.

Significantly different leucocyte profile between F2 fish from broodstock exhibiting marker and those from broods that did not are leucocyte differentiation, especially lymphocyte and neutrophyl (Table 3). The decrease of lymphocyte in fish whose parents exhibiting MHC I marker post bacterial infection is lower compared to those whose parent did not exhibit MHC I marker. The decreased in lymphocyte count after challenge in F2 fishes whose parent exhibit MHC marker was lower compared to those whose parent did not exhibit MHC I marker. In contrast, the increase in neutrophyl count of their progenitor did not exhibit MHC I marker was higher compared to those whose parent exhibit MHC I marker. The difference in lymphocyte and neutrophyl count indicated the potential of using leucocyte differential parameter to identify fishes resistant to pathogenic bacterial infection. In addition, difference in lymphocyte and neutrophyl count showed their role in $A$. bydrophyla bacteria phagocytosis that resulted in F2 fish exhibiting MHC I marker showing higher survival (Hastuti \& Subandiyono 2015).

Lymphocyte count in healthy catfish ranges between $80.0-90.0 \%$, monocyte less than $15.13 \%$, and neutrophyl about $6.0-8.0 \%$ (Andayani et al. 2014). The lymphocyte count of fish challenged by bacteria (62.0-79.0\%) was less compared to unchallenged fish $(88.0-93.0 \%)$. This is in line with what was reported by Martins et al. (2008), that lymphocyte percentage decreased when an individual is suffering from disease infection. Neutrophyl of fish that were not challenged (4.0$7.0 \%$ ) was lower compared to fishes that were challenged (12.0-16.0\%). Neutrophyl has an active role in first phase of inflammation. Neutrophyl would be produced around the first 6 hour after inflammation (Kuby 1997). Thus, neutrophyl count would increase if inflammation caused by Aeromonas hydrophila bacterial infection occurs. F2 fish percentage with inflamation was a bit lower compared to fish whose parent did not exhibit MHC I marker. This support the lower neutrophyl count compared to fish whose parent did not exhibit MHC I marker. Monocyte count of fishes that were challenged was higher (9.0$14.0 \%$ ) compared to monocyte count of fish injected by PBS (2.0-5.0\%). The increase in monocyte count showed non-specific immune 
response from catfish's body against $A$. bydrophila pathogen.

Clinical symptoms observation was conducted 24-96 hours post challenge. Observed clinical symptoms were ulceration on skin and dropsy (edema) by the under belly of African catfish. From visual observation, about $40 \%$ of F2 offsprings of broods exhibiting MHC I marker suffered ulceration, however all control fish suffered ulceration. Other studies support the assertion that F2 fish from parents carrying the MHC I marker has a higher resistance than that of from parents without the marker.

Clinical symptoms shown by F2 catfish were similar with those reported by previous research. Clinical symptoms can be observed in 12-96 hours post infection. Clinical symptoms commonly observed in 24 hours post infection were swelling skin and inflammation around injection area of $A$. bydrophila. Afterward, fish would show dropsy, followed by ulceration (Wulandari et al. 2014). The behavior of fishes during challenged test were lowering appetite and irregular swimming pattern. Fishes tend to hang floating in the surface or passively at the bottom of the aquaria. Most of the fishes died with damaged fin and exuded mucus. According to Rey et al. (2009), fish infected by Aeromonas bydrophila will show dropsy or liquidfilled swelling belly, damaged meat or ulcer indicated by skin injury, and loss of blood. Infected fish will also show clinical symptoms such as irregular swimming or fish damage.

\section{Weight Gain and Survival Rate during Nursery}

F2 fish body weight gain and survival rate during nursery are presented in Table 4 . The initialbody weight of fishes reared for growth rate test was $0.11 \pm 0.03 \mathrm{~g}$. The results showed that daily growth rate (DGR) from two MHC I marker exhibiting F2 cross (cross B: $7.87 \%$ day $^{-1}$ and C: $8.32 \%$ day $^{-1}$ ) was higher $(\mathrm{p}<0.05)$ compared to control which did not exhibit the marker effect (D cross: $7.15 \%$ day $\left.^{-1}\right)$. However, DGR of fish cross A was the same as cross D ( $>0.05)$. Meanwhile, survival rate of all treatment fish was the same ( $>0.05)$. The water quality during nursery was 24.7-30.30C temperature, 7.40-7.60 $\mathrm{mg} \mathrm{L}^{-1}$ dissolved oxygen, $0.02-0.95 \mathrm{mgL}^{-1}$ ammonia and 6.4-7.70 pH.

Growth and survival determine aquaculture productivity level. In this research, F2 generation of African catfish was nursed in aquaria with relatively good water quality. In that condition, F2 African catfish from parents with MHC I marker (crosses B and C) had higher weight gain, while the survival was the same with African catfish with those that did not exhibit the marker (Table 4). Thus, cultivation of African catfish exhibiting MHC I marker has the potential in having higher productivity. However, weight gain vary among crosses, therfore, its necessary to choose parent that produces higher growth. In addition, it is most likely that no link between weight gain and presence of MHC marker in parent. Furthermore, if $A$. bydrophila bacterial infection exist, farmers that rear African catfish exhibiting MHC I marker has greater probability in getting higher harvest compared to those with fish without MHC I marker. The statement is supported by the result of this research, through A. bydrophila challenge with 2 higher survival compared to F2 fish whose parent did not exhibit the MHC I marker. This result is relatively consistent with what was reported by Azis et al. (2015b) in F1 generation of African catfish. This result also showed that MHC I marker expressing African catfish's resistance is stable. In

Table 4 Daily growth rate (DGR) and survival rate of second generation African catfish that exhibited MHC I marker and that did not exhibit MHC I marker, in relation to their endurance against Aeromonas bydrophila bacterial infection while kept in $80-\mathrm{L}$ volume aquaria for 2.0 months

\begin{tabular}{ccccc}
\hline \multirow{2}{*}{ Parameter } & \multicolumn{4}{c}{ Crosses } \\
\cline { 2 - 5 } & $\mathrm{A}$ & $\mathrm{B}$ & $\mathrm{C}$ & $\mathrm{D}$ \\
\hline DGR $(\% /$ day $)$ & $7.53 \pm 0.57^{\mathrm{ab}}$ & $7.87 \pm 0.28^{\mathrm{bc}}$ & $8.32 \pm 0.60^{\mathrm{c}}$ & $7.15 \pm 0.18^{\mathrm{a}}$ \\
Survival rate $(\%)$ & $90.00 \pm 3.33^{\mathrm{a}}$ & $98.30 \pm 3.33^{\mathrm{a}}$ & $95.80 \pm 3.85^{\mathrm{a}}$ & $96.70 \pm 3.30^{\mathrm{a}}$ \\
\hline
\end{tabular}

Note: $A=$ Cross of $R_{1} \times R_{1}$ African catfish broods exhibiting MHC I marker, $B=$ Cross of $R_{2} \times R_{2}$ African catfish broods exhibiting $M H C$ I marker, $C=C$ ross of $\mathrm{R}_{3} \mathrm{xR}_{3}$ African catfish broods exhibiting MHC I marker, $\mathrm{D}=$ Cross of African catfish control group that did not exhibit MHC I marker. Different superscript letter in the same row showed a significant difference $(\mathrm{p}<0.05)$. 
accordance to varieties from breeding in Indonesia, at least $\mathrm{F} 3$ generation is required to test the performance consistency of MHC I marker exhibiting African catfish before it could be released for public use. In fact the KHV resistant common carp strain developed through MHC II marker based selection (Alimuddin et al. 2011) has pass releas as a new fish strain at third generation in 2015.

\section{CONCLUSION}

Second generation African catfish from parents exhibiting MHC I marker is known to have higher growth rate and resistant against Aeromonas bydrophila bacterial infection compared to fish whose parents did not exhibit MHC I marker. MHC I marker is inherited by F2 generation, similar percentage to what is found in F1 generation. Further study is needed to observe whether the oligonucleotide primers anneals to another gene that having the same nucleotide at 3', and the PCR products are the same gene as that found in F2 fish from parents carrying the MHC I marker.

\section{ACKNOWLEDGEMENTS}

This research was partially supported by PSU Research Grant No.: 627/IT3.11/ PN/2016 from Ministry of Research and Higher Education, Indonesia.

\section{REFERENCES}

Alimuddin, Mubinun, Santika A, Carman O, Faizal I, Sumantadinata K. 2011. Identification of the Majalaya common carp strain resistance to KHV infection using Cyca-DAB $1 * 05$ allele as a marker. Indonesian Aquaculture Journal 6(2):157-63.

American Public Heatlh Association (APHA) [Internet]. 2005. Standard methods for the examination of water and wastewater. [cited 2016 Aug 28]. Available from: http://www.mwa.co.th/download/file_ upload/SMWW_1000-3000.pdf

Andayani, Marsoedi S, Sanoesi E, Wilujeng AE, Suprastiani H. 2014. Profil hematologis beberapa spesies ikan air tawar budidaya. [Hematology profile of freshwater fish species]. National Conference - Green Technology 3. p. 363-5.
Anderson DP, Siwicki AK. 1995. Basic hematology and serology for fish health programs. Manila (PH): Fish Health Section, Asian Fisheries Society.

Azis, Alimuddin, Sukenda, Zairin MJr. 2015a. Identifikasi kandidat marka MHC I pada ikan lele (Clarias sp.) tahan infeksi Aeromonas bydropbila. [Identification of MHC I marker candidate in catfish (Clarias sp.) resistance to Aeromonas bydrophila infection]. Jurnal Riset Akuakultur 10(2):261-9.

Azis, Alimuddin, Sukenda, Zairin MJr. 2015b. MHC I molecular marker inheritance and first generation catfish (Clarias sp.) resistance against Aeromonas bydrophila infection. Pak J Biotechnol 12(2): 131-7.

Blaxhall PC, Daisley KW. 1973. Routine hematological methods for use with fish blood. J Fish Biol 5(6):771-81.

Del Coral F, Shotts EB, Brown J. 1990. Adherence haemagglutination and cell surface characteristics of motile aeromonads virulent for fish. J Fish Dis 13(4):255-68.

Hastuti S, Subandiyono. 2015. Catfish (Clarias gariepinus Burch) well-being which maintained with biofloc technology. IJFST 10(2):74-9.

Kirpichnikov VS. 1999. Genetics and breeding of common carp. Paris (FR): INRA Editions.

Kuby J. 1997. Immunology. California (US): W.H Freeman and Company.

Li C, Wang R, Su B, Luo Y, Terhune J, Beck B, Peatman E. 2013. Evasion of mucosal defenses during Aeromonas bydropbila infection of channel catfish (Ictalurus punctatus) skin. Dev Comp Immunol 39(4):447-55.

Martins ML, Mouriño JLP, Amaral GV, Vieira FN, Dotta G, Jatobá AMB, ... Pereira-Jr G. 2008. Haematological changes in Nile tilapia experimentally infected with Enterococcus sp. Braz J Biol 68(3):657-61.

Ministry of Marine Affairs and Fisheries Republic of Indonesia (MMAF) [Internet]. 2016. MMAF developed environmental friendly method in catfish farming with biofloc. [cited 2016 Aug 28]. Available from: http://www.djpb.kkp.go.id/arsip/c/451/ kkp-kembangkan-teknologi-budidaya-ikan-leleramah-lingkungan-metode-biofok-untukkeberlanjutan/?category_id=

Rakus LK. 2008. Major histocompatibility (MH) polymorphism of common carp link with disease resistance [Thesis]. Retreived from Wageningen University.

Rey A, Verjan N, Ferguson HW, Iregul C. 2009. Pathogenesis of Aeromonas bydrophilla strain KJ99 infection and its extracelullar products in two species of fish. Vet Rec 164(16):493-9. doi: 10.1136/vr.164.16.493 
Triyaningsih, Sarjito, Prayitno SB. 2014. Pathogenicity of Aeromonas bydrophila isolated from catfish (Clarias gariepinus) derived from Boyolali. JAMTech 3(2):117.

Wulandari A, Prayitno SB, Sarjito. 2014. Pathogenicity of K14 isolate which isolated from catfish (Clarias gariepinus) derived from Demak. JAMTech 3(2):1439.

Yanto H, Hasan H, Sunarto. 2015. Studi hematologi untuk diagnosa penyakit ikan secara dini di Sentra Produksi
Budidaya Ikan Air Tawar Sungai Kapuas Kota Pontianak. [Early fish disease diagnose through haematological analysis in Main Center for Freshwater Aquaculture, Kapuas River, Pontianak]. Jurnal Akuatika 6(1):11-20.

Zhang D, Xu D-H, Shoemaker C. 2016. Experimental induction of motile Aeromonas septicemia in channel catfish (Ictalurus punctatus) by waterborne challenge with virulent Aeromonas bydrophila. Aquaculture Reports 3:18-23. 